\title{
An electrophoretic study of protein diversity in five species of land snails (Achatinidae) from Nigeria
}

\author{
Micheal Olufemi AWODIRAN 1, Joel Idowu AWOPETU 1, \\ Oludele Olayemi ODEKANYIN ${ }^{2 *}$ and Dupe Olufunke OGUNBOSOYE ${ }^{3}$ \\ ${ }^{1}$ Department of Zoology, Obafemi Awolowo University, Ile-Ife, Nigeria. \\ ${ }^{2}$ Department of Biochemistry, Obafemi Awolowo University, Ile-Ife, Nigeria. \\ ${ }^{3}$ National Centre for Genetic Resources (NACGRAB), Ibadan, Nigeria Biochemistry Department,Obafemi \\ Awolowo University, Ile-Ife, Nigeria. \\ *Corresponding Author, E-mail: dekanyin@oauife.edu.ng; deleodekanyin@yahoo.co.uk
}

Tel: +234806-287-9457

\begin{abstract}
The protein profile of five species of achatinid snails (Archachatina marginata (Swainson, 1821), Achatina achatina (Linnaeus, 1758), Achatina fulica (Bowdich, 1822), Archachatina papyracea (Pfeiffer, 1845 ) and an unidentified snail species) from some parts of southern and north-central states of Nigeria was used to examine the level of genetic similarity between them and also to show whether the eight populations of Archachatina marginata studied contained sub-populations. Each of the species examined was found to have unique protein bands while the protein banding patterns of the eight populations of A. marginata showed six of the populations being taxonomically distinct because they had unique protein bands. The cluster analysis of the A. marginata samples produced two sub-species which showed geographical separation of the species. This may depict a relationship between total protein and ecological adaptation. However, there was better resolution of the protein band patterns using relative mobility of bands. The presence of common bands among the species and the eight populations of $A$. marginata may depict an evidence of evolutionary origin of the species studied.
\end{abstract}

(c) 2013 International Formulae Group. All rights reserved.

Keywords: Achatina spp., Archachatina spp., protein, electrophoresis, taxonomy.

\section{INTRODUCTION}

The family Achatinidae consists of land snails containing about thirteen genera including Achatina (Linnaeus, 1758) and Archachatina (Swainson, 1821) which are native to Africa (Raut and Barker, 2002). They are very important protein source and are served as delicacies in south-western part of Nigeria. Classification within the group is based on conchological features (Bequaert,
1950) and the highly variable reproductive tract (Mead, 1991). Molluscs like many other invertebrates are poorly known because relationships between them are not clear while their taxonomic inferences are often hindered by a lack of morphological diversification between different lineages, as occurs in different cryptic species or species showing overlapping variability (Elejalde et al., 2008). 
Various biochemical differences between populations have proved valuable aids in determining taxonomic relationships. Gottlieb (1971) stated that electrophoresis has the advantage of showing that variation in band patterns can directly be equated to variation in genes coding for various proteins.

Several workers have underscored the importance of protein electrophoresis in elucidating level of similarity between populations of snails. Miyazaki et al. (1988) employed a two-dimensional electrophoresis method to compare the total protein components of two types (large and small forms) of the same species of land snail Tyrannophaedusa (Luchuphaedusa) ophiodoon (family Clausiliidae) and reported that there was a close relationship between the two forms based on the similarity of their protein band patterns. Diupotex-Chong et al. (2007) analyzed total proteins of Pomacea snails (Ampullaridae) to differentiate between Pomacea flagellata and P. patula catemacensis. The report showed that there were differences in the number of bands produced by the two species and that population of $P$. flagellata did not cluster according to any geographical pattern and was therefore not providing any taxonomically useful information.

Using disc-gel SDS-PAGE electrophoresis the protein profile of five species of achatinid snails was examined during the present study. The species studied were Achatina achatina (Linnaeus, 1758), Achatina fulica (Bowdich, 1822), Archachatina marginata (Swainson, 1821), Archachatina papyracea (Pfeiffer, 1845) and an unidentified species across three different vegetation zones of Nigeria with a view to showing their level of genetic similarity and also to see whether the eight populations of $A$. marginata studied contained sub-species or not.

\section{MATERIALS AND METHODS}

Sampling and collection sites

Figure 1 is the map of the study area showing the sampling sites. Samples were taken from three vegetation zones: the rainforest (this included the lowland rainforest of Edo State and the South-west), derived savanna, and guinea savanna of Nigeria. The vegetation varied from rainforest to savanna (Happold, 1987). The annual rainfall ranged from 1,000 $\mathrm{mm}$ to $2500 \mathrm{~mm}$ (Salako, 2007). Specimens of A. marginata were collected alive from eight locations (Table 1 and Figure 1). The other species (A. achatina, A. fulica, A. papyracea and one unidentified species) were collected from locations as shown in Table 1 over the same study period. The identification of the land snails was carried out according to Bequaert (1950) and Mead (1995).

\section{Homogenization of tissue}

Homogenization of the same weight $(1.5 \mathrm{~g})$ of hepatopancreas of the snails was carried out in 0.2 M Phosphate buffer ( $\mathrm{pH} 7.0$ ) containing $0.15 \mathrm{M} \mathrm{NaCl}$ and $0.01 \%$ Phenylmethylsulfonyl fluoride, which served as protease inhibitor. The homogenate was centrifuged at 25,000 rpm. The clear supernatant was removed and used as the crude protein sources.

\section{Sodium Dodecyl Sulphate- Polyacrylamide Gel Electrophoresis (SDS-PAGE)}

In the presence of Sodium Dodecyl Sulphate, disc gel electrophoresis was performed on various samples on $7.5 \%$ separating gel and $4.5 \%$ stacking gel as described by Weber and Osborn (1975) using the SDS-Tris-glycine buffer system at $\mathrm{pH} 8.8$. A volume of $0.1 \mathrm{ml}$ of the sample was added to $0.9 \mathrm{ml}$ of sample buffer $(0.01 \mathrm{M}$ Tris- $\mathrm{HCl}$, $1 \%$ SDS, $1 \% \beta$-mercaptoethanol, $\mathrm{pH} 7.2)$ and boiled for 5 mins in a boiling water bath. It was then allowed to cool to room temperature. Glycerol ( 2 drops) and $5 \mu$ l of tracking dye ( $0.2 \%$ Bromophenol blue) were added to the boiled sample. $50 \mu \mathrm{l}$ of the sample solution was layered on the stacking gel. 
Electrophoresis was carried out at room temperature at a constant current of 1 $\mathrm{mA} /$ gel during stacking and $3 \mathrm{~mA} / \mathrm{gel}$ during actual separation. The gels were stained in the staining solution made up of Coomassie Brilliant Blue R-250 (1.25g), $227 \mathrm{ml}$ methanol, $46 \mathrm{ml}$ glacial acetic acid and distilled water to make a total volume of $500 \mathrm{ml}$. The gels were destained in the destaining solution consisting of $5 \%$ methanol and $7.5 \%$ glacial acetic acid in distilled water.

\section{Protein data analysis}

The protein band patterns of the 12 populations studied were scored (manually for presence or absence of bands). Only reproducible and valuable bands were scored. The data were subjected to Jaccard cluster algorithm using the statistical software PAST (Hammer et al., 2006). This was employed to determine the similarity coefficient of the protein banding patterns. Furthermore, the relative band mobility of the protein banding patterns was also studied to ensure better and additional understanding of the protein distances and their relationships. This was done by measuring the relative distances of the bands to analyze the common and unique bands.

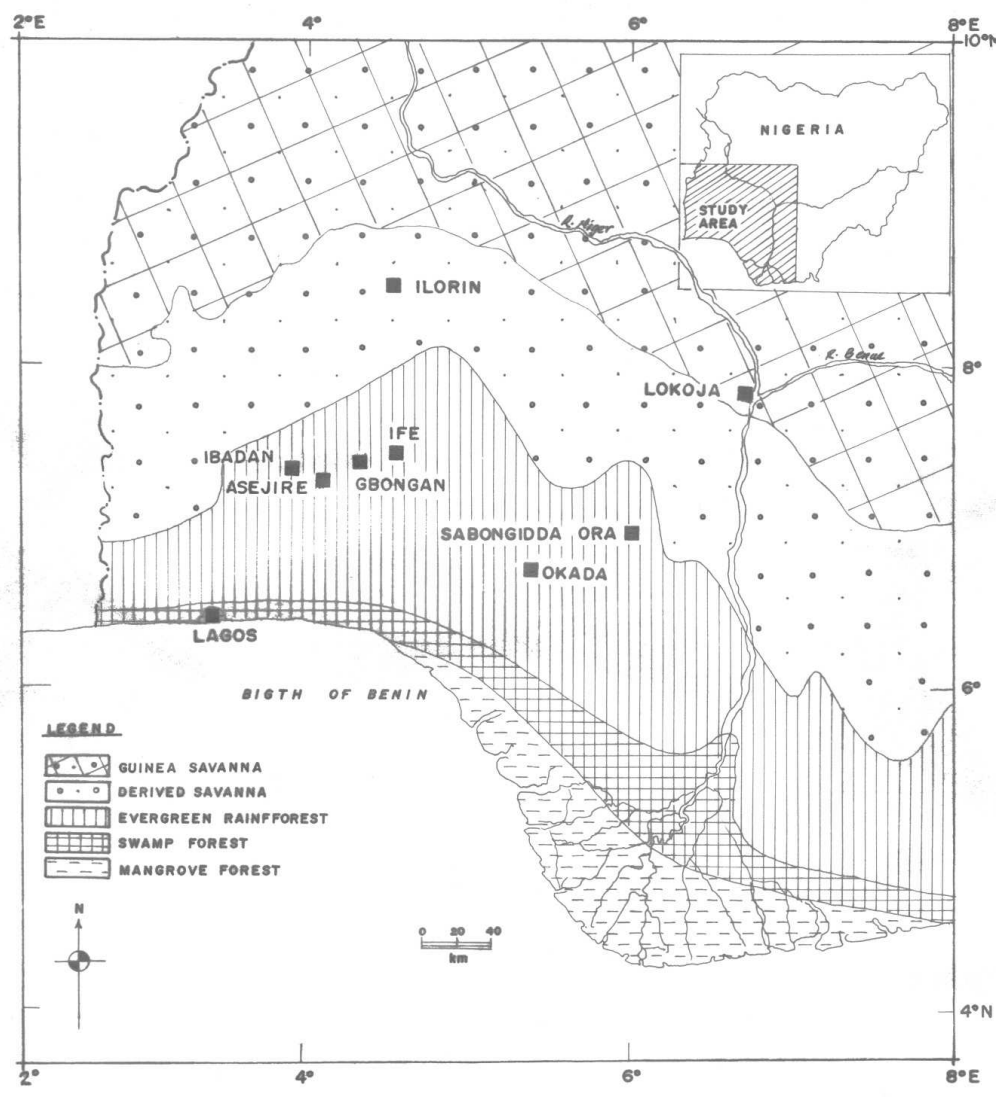

Figure 1: Map showing the sampling locations of Archachatina marginata, Achatina achatina, Achatina fulica, Archachatina papyracea and one unidentified species (Insert is the map of Nigeria) (Adapted from Rosevear, 1953). 
Table 1: Species of snail specimen collected from different locations and geographical coordinates in South-western Nigeria.

\begin{tabular}{|c|c|c|c|}
\hline species & zone & locality & $\begin{array}{l}\text { Geographical } \\
\text { coordinates }\end{array}$ \\
\hline \multirow{8}{*}{ Archachatina marginata } & \multirow{6}{*}{ Rainforest } & Asejire (As) & $07^{\circ} 20^{\prime} \mathrm{N} 004^{\circ} 07^{\prime} \mathrm{E}$ \\
\hline & & Ibadan (Ib) & $07^{\circ} 23^{\prime} \mathrm{N} 003^{\circ} 54^{\prime} \mathrm{E}$ \\
\hline & & Ife (If) & $07^{\circ} 28^{\prime} \mathrm{N} 004^{\circ} 34^{\prime} \mathrm{E}$ \\
\hline & & Gbongan (Gb) & $07^{\circ} 28^{\prime} \mathrm{N} 004^{\circ} 21^{\prime \prime} \mathrm{E}$ \\
\hline & & Okada (Ed) & $06^{\circ} 73^{\prime} \mathrm{N} 005^{\circ} 38^{\prime \prime} \mathrm{E}$ \\
\hline & & Sabongida Ora (Edo 1) & $06^{\circ} 54^{\prime \prime} \mathrm{N} 005^{\circ} 55^{\prime} \mathrm{E}$ \\
\hline & Derived savanna & Ilorin (IL) & $08^{\circ} 30^{\prime \prime} \mathrm{N} 004^{\circ} 33^{\prime \prime} \mathrm{E}$ \\
\hline & Guinea savanna & Lokoja & $09^{\circ} 05^{\prime} \mathrm{N} 007^{\circ} 32^{\prime \prime} \mathrm{E}$ \\
\hline \multirow[b]{2}{*}{ Achatina achatina } & \multirow[b]{2}{*}{ Rainforest } & Ibadan (Ib) & $07^{\circ} 23^{\prime \prime} \mathrm{N} 003^{\circ} 54^{\prime \prime} \mathrm{E}$ \\
\hline & & Ife (If) & $07^{\circ} 28^{\prime} \mathrm{N} 004^{\circ} 34^{\prime} \mathrm{E}$ \\
\hline Achatina fulica & Rainforest & Ibadan (Ib) & $07^{\circ} 23^{\prime \prime} \mathrm{N} 003^{\circ} 54^{\prime \prime} \mathrm{E}$ \\
\hline Archachatina papyracea & & Ibadan (Ib) & $07^{\circ} 23^{\prime} \mathrm{N} 003^{\circ} 54^{\prime \prime} \mathrm{E}$ \\
\hline Unidentified species & & Ibadan (Ib) & $07^{\circ} 23^{\prime} \mathrm{N} 003^{\circ} 54^{\prime \prime} \mathrm{E}$ \\
\hline
\end{tabular}

\section{RESULTS}

Figure 2 and Figure 3 show the protein gel electrophoretic bands and electrophoregrams of the four different species (A. achatina, A. fulica, A. papyracea and one unidentified species) and eight populations of the fifth species (A. marginata) of land snails. An examination of these patterns revealed distinct quantitative and qualitative intra and inter- specific variation in terms of the numbers, position and intensity of stain (very thick, thick, faintly thick, faint and very faint) of the bands. All the individuals examined produced varying number of bands. In all, eighty two bands were produced by the individuals sampled. Majority of the bands were similar in their position on the gel. However there are a few peculiar bands. Table 2 shows the number of peculiar bands in each sample. These bands are distributed as follows: A. achatina (2.7 and 5.2), A. papyracea (4.4 and 6.4), A. fulica (3.1), A. marginata populations of Okada (Edo 1) (6.8 and 7.6), A. marginata populations of Ilorin (6.7 and 8.0), A. marginata populations of Ibadan (1.1, 6.1 and 6.3), A. marginata populations of Asejire (1.7 and 4.2) and $A$. marginata populations of Lokoja (5.5). The bands are consistent (data not shown) and therefore could be used as markers. Interspecific bands were also observed between pairs of species/population as shown in Table 3. The highest number, four, occurs between A. marginata Sabongida Ora (Edo2) and A. marginata Ilorin, A. marginata Ilorin and A. marginata Gbongan, A. marginata Gbongan and A. marginata Asejire and $A$. marginata Sabongida Ora (Edo2) and $A$. marginata Lokoja.

There is more pairwise similarity among the eight populations of $A$. marginata than other species under study. 
Figure 4 shows the clustering patterns in the dendrogram based on protein banding pattern data of all the populations sampled. The Jaccard cluster algorithm shows very high genetic variation and very low similarity coefficient of about 5\% among the eight populations of $A$. marginata, and single population of each of A. achatina, A. fulica, A. papyracea and one unidentified species. The cluster also shows four clades with the fourth clade containing only the unidentified snail. Figure 5 shows the dendrogram of the protein banding profile of the eight populations of A. marginata which produces four sub-clusters. The intraspecific coefficient of similarity is very low (5\%). This means that there is a very high level of genetic heterogeneity within the various samples of $A$. marginata. Of note is the inclusion of samples of Sabongida Ora and Okada (AmSOE) and Lokoja in clade 1 while those of Gbongan and Asejire are found in clade 2. The dendrogram comprises essentially two main clades, clades 1 and 2, with $10 \%$ coefficient of similarity. The third clade has only one sub-population (Sabongida Ora-AmSOE) while the fourth one contains Ilorin and Ife sub-populations.

\section{DISCUSSION}

The analysis of the protein banding patterns of the populations studied, as shown in Table 2 showed that each of the species had unique protein bands. This may indicate that they were genetically separate.

The protein banding patterns of the eight populations of $A$. marginata also showed six subpopulations of Okada Edo 1, Sabongida Ora Edo 2, Ilorin, Ibadan, Asejire and Lokoja with unique bands which also indicated that each was taxonomically distinct from one another.

However, the other two populations (Gbongan and Ife) had no peculiar bands. This study also revealed that $A$. marginata population from Ibadan had the highest number of unique bands (three) which may mean that it was the most distinct of all the subpopulations.

Table 2: Relative mobility of protein bands of various populations of snail species.

\begin{tabular}{lcccccc}
\hline Species & $\begin{array}{c}\text { Total no. } \\
\text { of bands }\end{array}$ & $\begin{array}{c}\text { Slow } \\
\text { moving } \\
\text { bands }\end{array}$ & $\begin{array}{c}\text { Intermediate } \\
\text { moving } \\
\text { bands }\end{array}$ & $\begin{array}{c}\text { Fast } \\
\text { moving } \\
\text { bands }\end{array}$ & $\begin{array}{c}\text { Unique bands } \\
\text { (cm) }\end{array}$ & $\begin{array}{c}\text { No. of } \\
\text { Unique } \\
\text { bands }\end{array}$ \\
\hline A. achatina & 7 & 2 & 2 & 3 & $2.7,5.2$ & 2 \\
A.papyracea & 7 & 1 & 3 & 3 & $4.4,6.4$ & 2 \\
Achatina fulica & 6 & 1 & 3 & 2 & 3.1 & 1 \\
Unidentified sp. & 2 & - & 1 & 1 & - & - \\
A.marginata E 2 & 7 & 2 & 3 & 2 & 2.0 & 2 \\
A.marginata E 1 & 5 & 1 & 2 & 2 & $6.8,7.6$ & 2 \\
A. marginata IL & 8 & - & 3 & 5 & $6.7,8.0$ & 3 \\
A. marginata Ib & 13 & 5 & 2 & 6 & $1.1,6.1,6.3$ & - \\
A. marginata IF & 2 & - & 1 & 1 & - & - \\
A.marginata Gb & 7 & 3 & 2 & 2 & $1.7,4.2$ & 2 \\
A.marginata As & 9 & 2 & 2 & 5 & 5.5 & 1 \\
A.marginata LK & 8 & 2 & 3 & 2 & & \\
\hline
\end{tabular}


Table 3: Intra and interspecific band relationships among the snail species and populations.

\begin{tabular}{lllllllllllll}
\hline & A & B & C & D & E & F & G & H & I & J & K & $\mathbf{L}$ \\
\hline A & - & - & - & - & - & - & - & - & - & - & - & - \\
B & 2 & - & - & - & - & - & - & - & - & - & - & - \\
C & 2 & 1 & - & - & - & - & - & - & - & - & - & - \\
D & 0 & 0 & 1 & - & - & - & - & - & - & - & - & - \\
E & 1 & 2 & 2 & 1 & - & - & - & - & - & - & - & - \\
F & 1 & 1 & 1 & 1 & 1 & - & - & - & - & - & - & - \\
G & 1 & 1 & 3 & 2 & 4 & 1 & - & - & - & - & - & - \\
H & 2 & 1 & 3 & 2 & 2 & 1 & 4 & - & - & - & - & - \\
I & 0 & 1 & 0 & 0 & 1 & 0 & 1 & 0 & - & - & - & - \\
J & 2 & 0 & 1 & 2 & 1 & 1 & 2 & 4 & 1 & - & - & - \\
K & 1 & 1 & 2 & 1 & 2 & 0 & 2 & 2 & 1 & 4 & - & - \\
L & 1 & 2 & 1 & 1 & 4 & 1 & 3 & 2 & 1 & 2 & 2 & - \\
\hline
\end{tabular}

$\mathrm{A}=$ Achatina achatina $; \mathrm{B}=$ Archachatina papyracea $; \mathrm{C}=$ Achatina fulica $; \mathrm{D}=$ Unidentified snail species $1 ; \mathrm{E}=$ A. marginata Edo 2; $\mathrm{F}=$ A.marginata Edo 1; $\mathrm{G}=$ A marginata Ilorin ; $\mathrm{H}=$ A.marginata $\mathrm{Ibadan} ; \mathrm{I}=$ A.marginata Ife; $\mathrm{J}=A$. marginata Gbongan; $\mathrm{K}=$ A.marginata, Asejire; $\mathrm{L}=$ A.marginata Lokoja

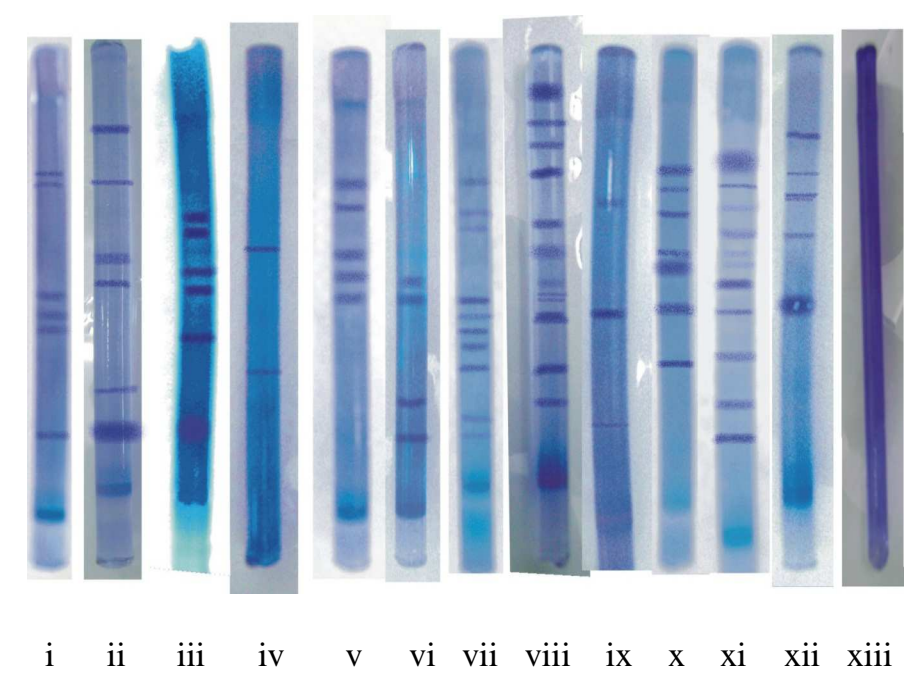

Figure 2: A typical Coomassie-Blue stained SDS-PAGE gel electrophoresis showing protein banding patterns for each of the twelve populations compared with a blank.

(i) Achatina achatina (ii) Archachatina papyracea (iii) Achatina fulica (iv) Unidentified species (v) Archachatina marginata Okada Edo 2 (vi) Archachatina marginata Sabongida Ora Edo 1 (vii) Archachatina marginata Ilorin (viii) Archachatina marginata Ibadan (ix) Archachatina marginata Ile Ife (x) Archachatina marginata Gbongan (xi) Archachatina marginata Asejire (xii) Archachatina marginata Lokoja (xiii) Blank. 
M. O. AWODIRAN et al. /Int. J. Biol. Chem. Sci. 7(1): 86-95, 2013

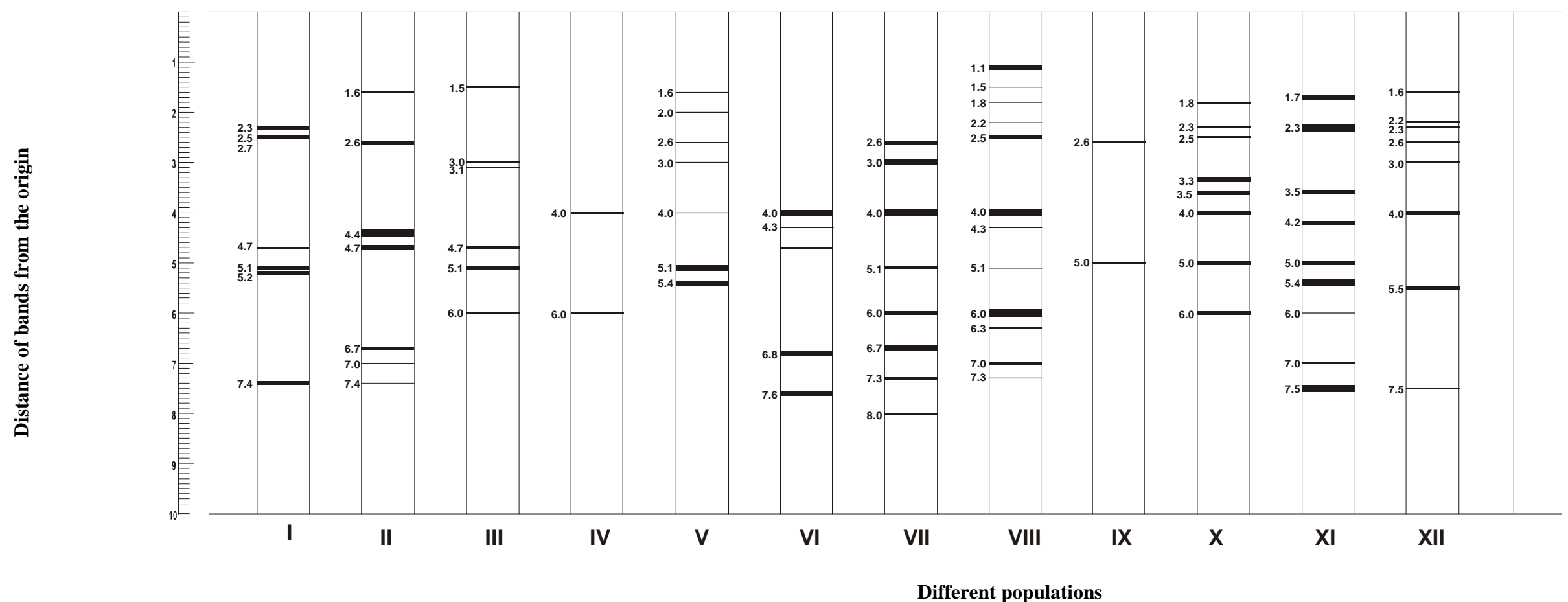

Figure 3: Schematic diagrams of the electrophoregrams of the twelve populations of five species.

(i) Achatina achatina; (ii) Archachatina papyracea; (iii) Achatina fulica; (iv) Unidentified Species ; (v) Archachatina marginata Okada Edo2; (vi) Archachatina marginata Sabongida Ora Edo1; (vii) Archachatina marginata Ilorin; (viii) Archachatina marginata Ibadan; (ix) Archachatina marginata Ile-Ife; (x) Archachatina marginata Gbongan; (xi) Archachatina marginata Asejire; (xii) Archachatina marginata Lokoja. 


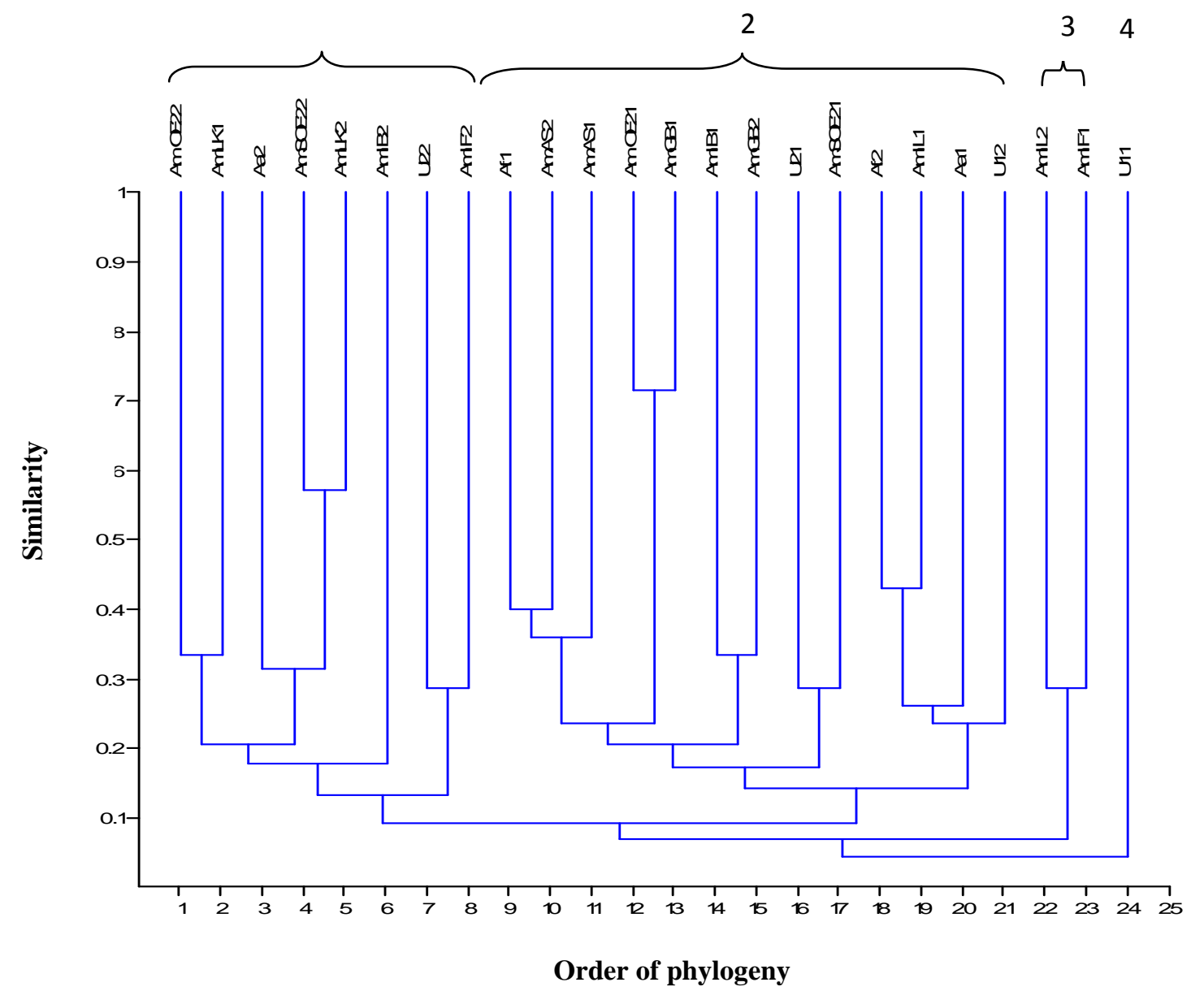

Figure 4: Dendrogram showing similarity coefficients based on protein profile data of the eight populations of Archachatina marginata, one each of Achatina achatina, Achatina fulica Archachatina papyracea and one unidentified snails' species.

AmAS1- Archachatina marginata Asejire 1 AmAS2 - Archachatina marginata Asejire 2 AmGb1 - Archachatina marginata Gbongan 1 AmGb2 - Archachatina marginata Gbongan 2 AmIB1 - Archachatina marginata Ibadan 1 AmIB2 - Archachatina marginata Ibadan 2 AmIF1 - Archachatina marginata Ile-Ife 1 AmIF2 - Archachatina marginata Ile-Ife 2 AmOE1 - Archachatina marginata Okada Edo 1 AmOE2 - Archachatina marginata Okada Edo 2 AmSOE1 - Archachatina marginata Sabongida Ora Edo 1 AmSOE2 - Archachatina marginata Sabongida Ora Edo 2
AmIL1 - Archachatina marginata Ilorin 1 AmIL2 - Archachatina marginata Ilorin 2

AmLK1 - Archachatina marginata Lokoja 1 AmLK2 - Archachatina marginata Lokoja 2

Aa11 - Achatina achatina 11 Ibadan Aa12 - Achatina achatina 12 Ibadan Af11 - Achatina fulica 11 Ibadan Af12 - Achatina fulica 12 Ibadan

U11 - Unidentified snail 11 Ibadan U12 - Unidentified snail 12 Ibadan U21 - Archachatina papyraceal Ibadan U22 - Archachatina papyracea 2 Ibadan 


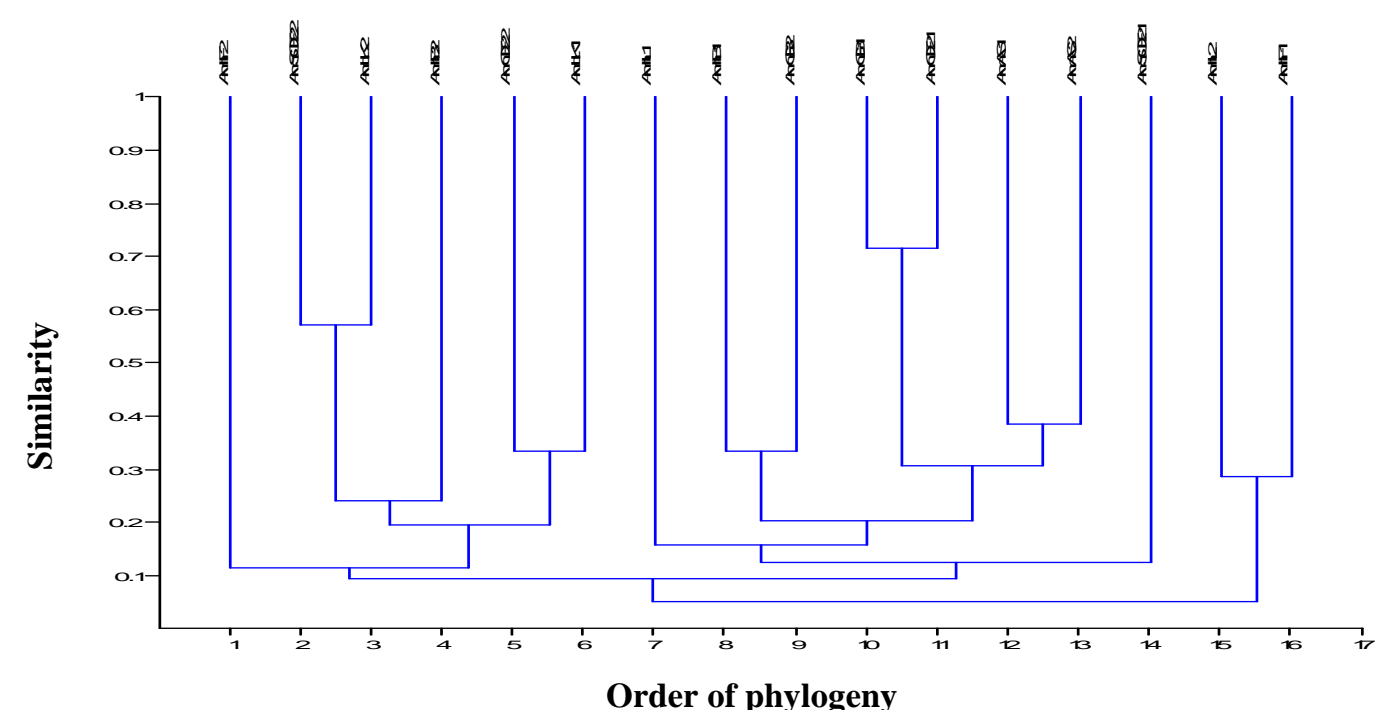

Figure 5: Dendrogram showing similarity coefficients based on protein profile data of samples of Archachatina marginata from eight different locations.

*KEYS are the same as those shown in Figure 4 above.

El-Khayat et al. (2008) used SDSPAGE profile of tissue protein to show that the mating system in Biomphalaria alexandrina have specific bands in snails bred by self-fertilization.

The presence of common bands (though not shown) among the various species studied and the eight populations of $A$. marginata may depict an evidence of evolutionary origin of the species studied. It may also suggest that proteins were under the control of the same gene. The diversity of protein bands is indicative of genetic diversity and may be useful in delimitation of $A$. marginata.

To depict the relationships among the species / populations studied based on their protein banding patterns, the cluster analysis was also employed. This method has also been used by Nisar et al. (2009). The cluster analysis of the protein-pattern characters indicated that the samples of four species of land snails; Archachatina marginata, Achatina achatina, Achatina fulica, Archachatina papyracea and the unidentified species were separated into four main clades. The first three species earlier mentioned and A. papyracea were monophyletically derived with the unidentified species forming the origin. According to Iloh et al. (1993) and Khalik et al. (2012) genetic similarity is based on the similarity of the proteins represented by the bands therefore low similarity depicts high genetic divergence among the snail species.

The protein bands of $A$. marginata samples from various locations of study also gave three clades while the basal clade diverge into two sub-clades which may probably imply that the populations contained two sub-species. This was obviously at variance with the finding based on relative mobility of bands which produced six distinct separations of the A. marginata populations in this study. It was obvious that there was a better resolution of the protein pattern characters with the use of the relative mobility of bands. Bakry and El Garly (2011) have also used electrophoretic analysis of tissue protein to determine the relationships between two species of snail, Biomphalaria alexandrina and Bulinus truncates. Although, total protein gel - electrophoresis is relatively accurate in detecting many amino acid differences between proteins encoded by alternative alleles of the same gene, and so is considered a good tool for studying population genetic structure, its distinct limitation is that not all nucleotide substitutions result in changes detectable by the technique (Mahmoud et al., 2010). In spite of this obvious limitation, the polymorphic nature of the shell of snail species studied, no doubt is congruous with the high diversity shown by their protein profile. Therefore to get a better resolution of 
the genetic variation among the populations of $A$. marginata and other species studied, there is a further need to employ the use of DNA sequencing.

In conclusion, there is a very high genetic variation among all the populations of five species of land snails studied and the analysis of eight different populations of Archachatina marginata showed a great potential of delimitation into at least two or more subspecies.

\section{REFERENCES}

Bakry FA, El-Garhy MF. 2011. Comparative study of the karyotypes and electrophoretic patterns of Biomphalaria alexandrina and Bulinus truncatus and the ova of their corresponding trematode hosts. J. Evol. Biol. Res., 3(3): 22-28.

Bequaert JC. 1950. Studies in the Achatininae, a group of African land snails. Bull. Mus. Comp. Zoo., 105(2): 1-126.

Diupotex- Chong ME, Cazzinga NJ, UribeAlcocer M. 2007. Karyological and Electrophoretic differences between Pomacea flagellata and P. Patula catemacensis (Caenigastropoda: Ampullariidae). Biocell: 31(1):3-9.

Elejalde MA, Madeira MJ, Arrebola, JR, Munoz B, Gomez-Moliner, BJ. 2008. Molecular Phylogeny, taxonomy and evolution of the land snail genus Iberus (Pulmonata: Helicidae). J. Zool. Syst. Evol. Res., 46(3): 193-202.

El-Khayat HM, Abu El Einin HM, Gawish FA. 2008. Determination of allozyme, protein and schistosome susceptibility in Biomphalaria alexandrina progenies produced by self and cross fertilization. $J$. Egypt Soc. Parasitol., 38(3): 1007-1024.

Gottlieb LD. 1971. Gel Electrophoresis: New Approach to the study of Evolution. Bio Science, 21: 939-944.

Hammer Ø, Harper DAT, Ryan PD. 2006. PAST -Paleontological Statisticsversion1.58. http://folk.uio.no/ohammer/ past.

Happold DCD. 1987. The Mammals of Nigeria. Clarendon Press: Oxford; 402.

Illoh HC, Ijogun OO, Bakare OA. 1993. An electrophoretic study of protein diversity in the seeds of the Genus Sida in Nigeria. Nig. J. Bo., 6: 13-20.
Khalik KA, Osman G, Al-Amoudi W. 2012. Genetic diversity and taxonomic relationship of some Ipomoea species based on analysis of RAPD-PCR and SDS-PAGE of seed proteins. Austr. J. Crops Sci., 6(6): 1088-1093.

Mahmoud MAM, El-Akad SS, Zalat SM., Awni SA. 2010. Polymorphism in the Protein of the thoracic muscle of an endemic bee (Anthophora pauperata) in the St. Katherine Protectorate. Egy. J. Biol., 12: 6-11.

Mead AR. 1991. Anatomical criteria in the systematics of the Achatinidae (Pulmonata). Proceedings of the $10^{\text {th }}$ International Malacological Congress, Meier-Brook C (ed). Tubingen, pp 549553.

Mead AR. 1995. Anatomical studies reveal new phylogenetic interpretations in Lissachatina (Pulmonata: Achatinidae). $J$. Mollus. Stud., 61(2): 257-273.

Miyazaki J, Ueshima R, Hirabayashi T. 1988. Application of a two-dimensional Electrophoresis method to the systematic study of land snails of subgenus Luchuphaedusa from southwestern Japan Islands. Biol. Bull., 175: 372-377.

Nisar M, Ghafoor A, Khan MR, Subhan M. 2009. Genetic similarity of Pakistan pea (Pisum sativum L.) Germplasm with world collection using Cluster Analysis and Jaccard's similarity index. J. Chem. Soc. Pak., 31(1): 138-144.

Raut SK, Barker GM. 2002. Achatina fulica Bowdich and other Achatinidae aspests in tropical agriculture, In Molluscs as Crop Pests, Barker GM (ed). CABI Publishing: Wallingford; 60.

Rosevear DR. 1953. Checklist and Atlas of Nigerian Mammals with a Foreword on Vegetation. Howard Doulton \& Co., Ltd. Associated Staples Press Co.: London; 238.

Salako FK. 2007. Temporal variation of rainfall erosivity in Southern Nigeria. Asset Series A, 7: 190-202.

Weber K, Osborn M. 1975. Protein and sodium dodecyl sulphate: molecular weight determination on polyacylamide gels and related procedures. In The Proteins ( ${ }^{\text {rd }}$ edn), Neurath H, Hill RL (eds). Academic Press: New York; 179223. 